\title{
COLLABORATIVE ACADEMIC SUPERVISION TO IMPROVE INSTRUCTIONAL COMPETENCY IN IMPLEMENTATION CURRICULUM 2013 IN ALIAN DISTRICT
}

\author{
Karsiyem \\ UPTD Pendidikan Unit Kecamatan Alian, Kebumen \\ karsiyem426@gmail.com
}

\section{Article History}

accepted 30/09/2018

approved 12/10/2018

published 30/10/2018

Keywords

supervisi akademik kolaboratif, individual, kemampuan guru

\begin{abstract}
Tujuan Penelitian Tindakan Sekolah ini adalah ingin memperoleh informasi bahwa supervisi akademik pendekatan kolaboratif teknik individual dapat meningkatkan kemampuan dalam pembelajaran dengan menerapkan Kurikulum 2013 bagi guru kelas I di sekolah binaan Kecamatan Alian tahun 2018. Hasil penelitian menunjukkan bahwa supervisi akademik pendekatan kolaboratif teknik individual dapat meningkatkan kemampuan pembelajaran dengan menerapkan Kurikulum 2013 pada guru kelas I di sekolah binaan Kecamatan Alian tahun 2018. Hal ini terbukti pada hasil penelitian dari setiap siklus kemampuan pembelajaran dalam menerapkan Kurikulum 2013 bagi guru kelas I meningkat. Pada kondisi awal nilai rata-rata silabus guru kelas I adalah 62, 9. Nilai rata-rata RPP guru kelas I adalah 65, 7. Nilai rata-rata pelaksanaan pembelajaran dengan menerapkan Kurikulum 2013 guru kelas I adalah 64,7. Siklus I nilai rata-rata silabus 72,6. Nilai rata-rata $\operatorname{RPP} 72,2$, dan nilai rata-rata pelaksanaan pembelajaran dengan menerapkan Kurikulum 2013 adalah 70,6. Pada siklus II nilai rata-rata silabus 74,8 . Nilai ratarata $R P P 77,0$. Nilai rata-rata pelaksanaan pembelajaran dengan menerapkan Kurikulum 2013 adalah 79,3. Siklus III nilai rata-rata silabus 79,8. Nilai rata-rata RPP 81,5. dan nilai rata-rata pelaksanaan pembelajaran dengan menerapkan Kurikulum 2013 adalah 83,9.Dengan demikian penelitian ini dinyatakan berhasil.
\end{abstract}

Social, Humanities, and Education Studies (SHEs): Conference Series https://jurnal.uns.ac.id/shes 


\section{PENDAHULUAN}

Keberhasilan penerapan Kurikulum 2013 ditentukan oleh guru, kepala sekolah, dan tenaga kependidikan. Namun, sosok yang utama dalam penerapan kurikulum itu adalah guru. Kementerian Pendidikan dan Kebudayaan menyoroti bahwa pemahaman dan kesiapan ketiganya dalam menerapkan kurikulum 2013 pada proses pembelajaran menjadi kunci utama keberhasilan implementasi Kurikulum 2013. Guru dengan dukungan penuh kepala sekolah dan bantuan profesional dari pengawas sekolah memiliki peran yang sangat penting dalam menentukan keberhasilan peserta didik.

Kehadiran guru yang profesional dan memahami serta menguasai kecakapan abad 21 memegang peranan penting dalam mewujudkan peserta didik yang cerdas, tangguh, mandiri dan mampu bersaing dengan bangsa lain di dunia dengan tetap menjunjung tinggi budaya dan karakter bangsa," kata Sekretaris Ditjen Guru dan Tenaga Kependidikan E. Nurzaman. (Baca: Mendikbud: Kurikulum yang Sesungguhnya adalah Para Guru)

Pemerintah menegaskan guru merupakan penentu utama dalam mempersiapkan peserta didik untuk mampu menghadapi tantangan besar abad 21. Dengan mengimplementasikan Kurikulum 2013, guru dan tenaga kependidikan di sekolah harus mampu mempersiapkan peserta didik menjadi sumber daya manusia yang handal agar mampu bersaing di masa depan. Untuk itu, guru sebagai pendidik bersama tenaga kependidikan di sekolah dituntut untuk mampu mengimplementasikan Kurikulum 2013 dengan mengembangkan kecakapan abad 21 dalam proses pembelajarannya.

Penerapan Kurikulum 2013 Plt Dirjen Guru dan Tenaga Kependidikan Hamid Muhammad mengatakan seluruh sekolah akan menerapkan Kurikulum 2013 pada tahun ajaran 2018/2019 (Dok. Humas Kemendikbud) Pemerintah telah menerapkan Kurikulum 2013 secara bertahap mulai tahun pelajaran 2014/2015. Penerapkan Kurikulum 2013 memang berbeda dengan kurikulum lainnya. Dulu, guru berfungsi sebagai pengajar. Tapi, saat ini guru harus menjadi fasilitator pembelajaran dengan mengintegrasikan kecakapan abad 21 selama proses pembelajaran. Pengembangan kecakapan abad 21 dalam pembelajaran. Untuk itu guru hendaknya memahami dan mampu mengembangkan kecakapan abad 21 dalam proses pembelajaran yang meliputi 3 hal, yakni: (1) Penguatan Pendidikan Karakter (PPK) (2) Kompetensi 4 K (3). Kecakapan literasi dasar

Pemerintah menegaskan bahwa seluruh sekolah wajib menerapkan Kurikulum 2013 pada tahun ajaran 2018/2019. Pemerintah memang telah melakukan pendampingan itu untuk memperkuat pemahaman mengenai Kurikulum 2013. kepada guru dan kepala sekolah.

Namun berdasarkan kenyataan, di sekolah binaan penulis dari sepuluh SD binaan baru tiga SD yang gurunya mendapat kesempatan mengikuti pelatihan dari Dinas Pendidikan Kabupaten Kebumen yaitu SDN 1 Surotrunan, SDN 3 Kalirancang, dan SDN 1 Bojongsari. Adapun masih ada 7 sekolah yang gurunya belum memperoleh pelatihan tentang pembelajaran dengan penerapan Kurikulum 2013. SD tersebut yaitu SDN 2 Surotrunan, SDN 2 Bojongsari, SDN 3 Bojongsari, SDN 1 Krakal, SDN 2 Krakal, SDN 4 Krakal, dan SDN 1 Seliling. Di sisi lain tahun pelajaran 2018/2019 pemerintah mewajibkan semua sekolah tanpa terkecuali harus melaksanakan Kurikulum 2013. 
Selain itu, berdasarkan hasil supervisi penulis selaku pengawas dari 3 sekolah yang sudah menerima pelatihan Kurikulum 2013 gurunya dalam melaksanakan pembelajaran belum sepenuhnya mengacu pada kurikulum 2013. Mereka masih mendominasi dalam proses pembelajaran. Pembiasaan literasi juga kurang maksimal. Selain itu juga, pembiasaan pengembangan abad 21 juga belum tampak. Pembelajaran cenderung terpusat pada guru. Guru dituntut untuk dapat melaksanakan pembelajaran secara tematik dengan menerapkan model-model pembelajaran agar tercipta suasana belajar yang lebih alamiah, sesuai kebutuhan, holistik, aktif, inovatif, kreatif, efektif, dan tetap menyenangkan bagi peserta didik. Karena dalam pembelajaran tematik memiliki kekuatan-kekuatan sebagai berikut : (1) memberikan pengalaman yang relevan dengan tingkat perkembangan dan kebutuhan anak, menyenangkan, karena bertolak dari minat dan kebutuhan anak, (2) hasil belajar dapat bertahan lama karena lebih berkesan dan bermakna, (3) mengembangkan keterampilan berpikir anak sesuai dengan permasalahan yang dihadapi, (4) menumbuhkan keterampilan sosial dalam bekerjasama, (5) memiliki sikap toleransi, komunikasi dan tanggap terhadap gagasan orang lain serta menyajikan kegiatan yang bersifat pragmatis sesuai dengan permasalahan yang ditemui.

Atas dasar dari temuan di atas, penulis selaku pengawas sekolah di sekolah binaan terpanggil untuk melaksanakan tugas kepengawasan sekolah yang mendesak terhadap guru saat ini yaitu memberikan tindakan nyata pada guru dalam pembelajaran dengan menerapkan Kurikulum 2013; mulai dari menyusun silabus, menyusun RPP dan melaksanakan pembelajaran dengan penerapan Kurikulum 2013.

Penerapan Kurikulum 2013 menuntut guru yang kreatif, profesional dan menyenangkan yang harus memiliki konsep dan cara untuk mendongkrak kualitas pembelajaran. Oleh karena itu guru dituntut untuk memiliki kemampuan mengembangkan pendekatan dan memilih metode pembelajaran yang efektif. Hal ini penting terutama untuk menciptakan iklim pembelajaran yang kondusif dan menyenangkan yang pada muaranya akan memberikan hasil yang berkualitas. Penerapan Penguatan Pendidikan karakter, pembiasaan literasi dasar, kemampuan C 4; kreatif, kritis, kolaboratif, komunikasi.

Sebagian besar guru dalam pembelajaran masih melihat segala sesuatu sebagai satu keutuhan (holistik) serta mampu memahami hubungan antara konsep secara sederhana. Proses pembelajaran masih bergantung kepada objek-objek konkrit dan pengalaman yang dialami secara langsung. Tetapi masalahnya guru belum terlatih melaksanakan pembelajaran secara tematik, karena banyak guru yang belum memahami bagaimana menyusun RPP dengan menerapkan Kurikulum 2013. Jika dalam menyusun RPP saja masih kesulitan maka tidak heran bila dalam pelaksanaan proses belajar mengajar juga kesulitan. Hal itu bisa kita maklumi RPP yang digunakan guru bukan karyanya sendiri melainkan hanya copy paste RPP terdahulu atau membeli yang sudah jadi.

Banyak alternatif yang dapat pengawas lakukan berkaitan dengan permasalahan tersebut. Pada kesempatan ini penulis selaku pengawas dabin akan memberikan tindakan pemecahan masalah dengan memberikan tindakan melalui supervisi akademik dengan pendekatan kolaboratif dengan teknik individual untuk meningkatkan kemampuan dalam pembelajaran dengan menerapkan Kurikulum 2013 pada guru kelas I di sekolah binaan. Oleh karena itu, penelitian ini untuk melihat kemampuan guru di sekolah binaan sekaligus sebagai balikan bagi pengawas sekolah secara komprehensip. 
Penelitian ini pengawas lakukan melalui kegiatan KKG dan dilanjutkan kunjungan ke sekolah-sekolah binaan. Secara umum gambaran tindakan yang dilakukan pengawas melalui pendekatan kolaboratif, kemudian pembimbingan, teknik individual.

Harapan penulis semoga guru dapat melaksanakan pembelajaran sehari-hari, dengan menerapkan Kurikulum 2013 dan berupaya untuk meningkatkan mutu pembelajaran di kelasnya. Oleh karena itu penulis tertarik melakukan penelitian tindakan sekolah dengan judul "Supervisi Akademik Pendekatan Kolaboratif Teknik Individual untuk Meningkatkan Kemampuan Pembelajaran dengan Menerapkan Kurikulum 2013 pada Guru Kelas I di Sekolah Binaan Tahun 2018".

\section{METODE PENELITIAN}

Penelitian Tindakan Sekolah (PTS) ini dilaksanakan di sekolah binaan Kecamatan Alian Kebumen terdiri dari sepuluh sekolah dasar yaitu (1) SDN 1 Surotrunan (2) SDN 2 Surotrunan (3) SDN 1 Bojongsari (4) SDN2 Bojongsari, (5) SDN 3 Bojongsari, (6) SDN 1 Seliling, (7) SDN 3 Kalirancang (8) SDN 1 Krakal (9) SDN 2 Krakal (10) SDN 4 Krakal. Kesepuluh sekolah dasar tersebut merupakan sekolah binaan dengan SD Inti yaitu SDN 1 Surotrunan. Subjek dan sekaligus objek dalam penelitian ini adalah guru kelas I di sekolah binaan sebanyak 10 orang. Sumber data dalam penelitian ini diperoleh dari hasil pengamatan/observasi, studi dokumen. Pengamatan dilakukan pada waktu pelaksanaan pembelajaran. Selain itu, juga digunakan untuk mengamati produk silabus dan RPP yang disusun guru. Studi dokumen dilakukan waktu peneliti menelaah silabus dan RPP yang dilakukan pada kondisi awal.Validasi data yang digunakan dengan teknik triangualasi. Adapun analisis data yang digunakan yaitu dengan deskriptif kuantitatif dan deskriptif kualitatif. Analisis kuantitatif digunakan untuk menghitung nilai dalam penyusunan silabus, RPP, dan pelaksanaan pembelajaran. Analisis Deskriptif digunakan untuk mendeskripsikan guru waktu melaksanakan pembelajaran. Prosedur penelitian yang digunakan dalam penelitian ini terdiri dari 3 siklus. Setiap siklus terdiri dari 4 tahapan; (1) perencanaan (2) pelaksanaan (3) pengamatan (4) refleksi.

\section{HASIL PENELITIAN DAN PEMBAHASAN}

Untuk meningkatkan kemampuan pembelajaran dengan menerapkan Kurikulum 2013 bagi guru kelas I di sekolah binaan Kecamatan Alian dilakukan dengan supervisi akademik pendekatan kolaboratif teknik individual di sekolah binaan Kecamatan Alian. Penelitian dilaksanakan dalam 3 siklus. Dalam pelaksanaan dapat digambarkan sebagai berikut.

1. Temuan sebelum dilaksanakan penelitian (Kondisi Awal)

a. Rata-rata guru kelas I dalam melaksanakan pembelajaran dengan menerapkan Kurikulum 2013 tidak dilaksanakan sesuai ruh Kurikulum 2013. Pembelajaran masih bersifat konvensional.

b. Dalam pembelajaran penguatan nilai karakter masih lemah.

c. Dalam pembelajaran Pembiasaan Literasi dasar juga belum dilaksanakan secara maksimal.

d. Dalam pembelajaran Pembiasaan pengembangan berpikir abad 21 masih belum tampak.

e. Dalam pembelajaran pembiasaan berpikir tingkat tinggi (High Oder Thingking Skill) belum maksimal. 
Komponen Silabus

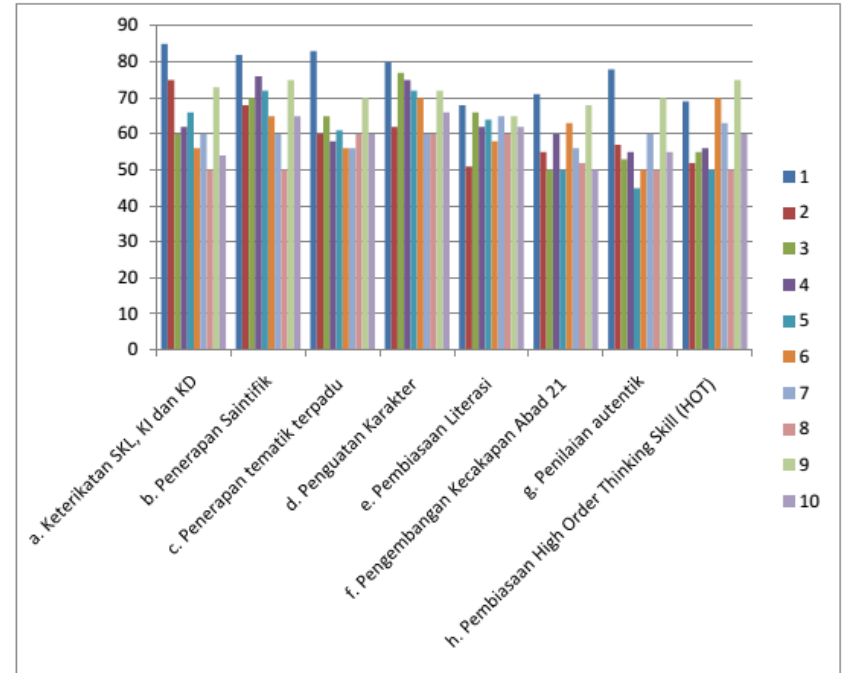

Komponen RPP

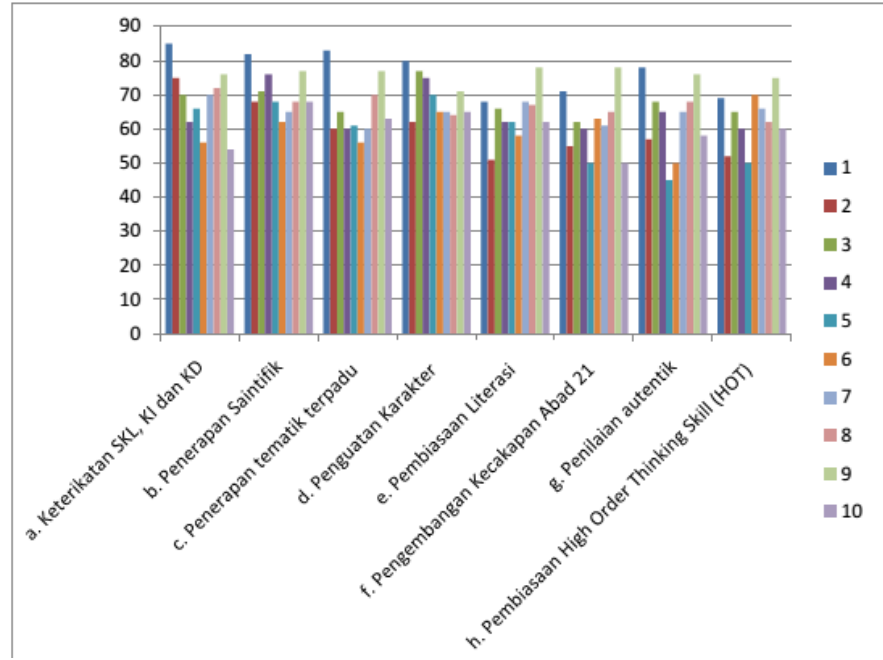

Komponen Pelaksanaan Pembelajaran

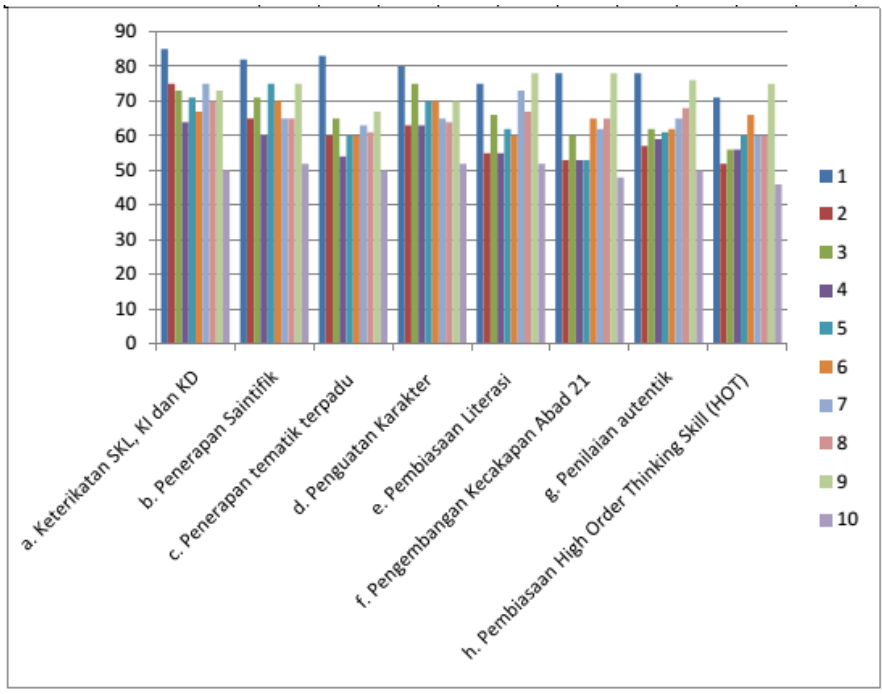


2. Temuan pada Siklus I

a. Semua guru kelas I dan supervisor membuat komitmen untuk melaksanakan pembelajaran dengan menerapkan Kurikulum 2013 dengan baik.

b. Supervisor telah melaksanakan supervise akademik pendekatan kolaboratif di KKG dengan melaksanakan workshop tentang Kurikulum 2013. Diakhir kegiatan workshop guru menyusun silabus dan RPP. Kemudian guru melaksanakan praktik pembelajaran.

c. Supervisor dan guru menelaah hasil supervise yang berupa penilaian penyusunan silabus, RPP, dan praktik pelaksanaan pembelajaran.

d. Dari hasil rekap penilaian disimpulkan bahwa kemampuan guru kelas I dalam melaksanakan pembelajaran dengan menerapkan Kurikulum 2013 sudah peningkatan, namun belum dapat mencapai indicator kinerja yang ditetapkan.

e. Perlu diadakan kegiatan tindakan pada siklus berikutnya untuk memperbaiki dengan pembimbingan secara individual dari supervisor tentang penguatan nilai karakter, dan literasi dasar.

\section{Komponen Silabus}

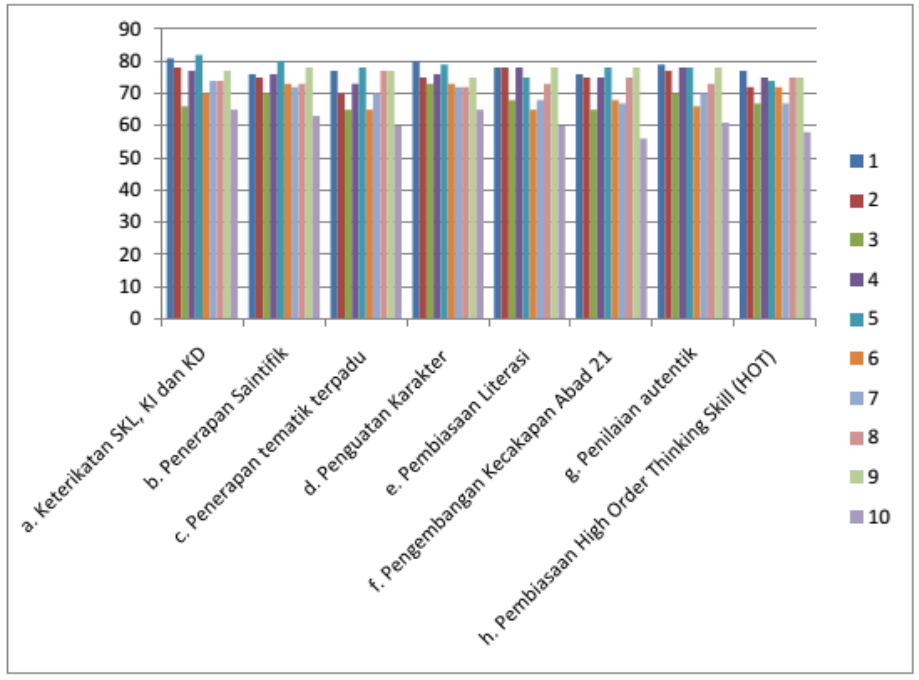

\section{Komponen RPP}

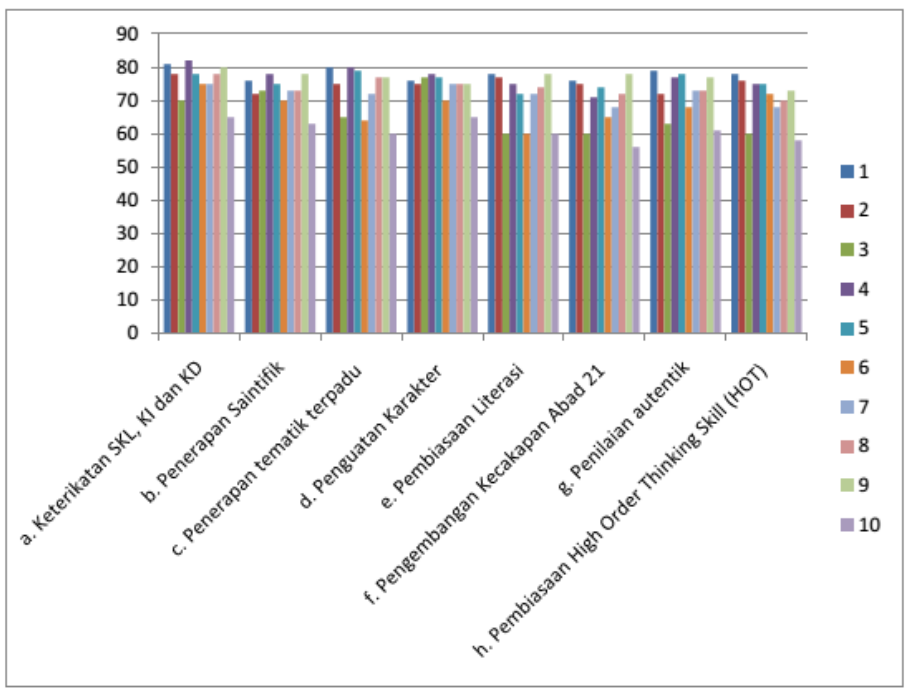




\section{Komponen Pelaksanaan Pembelajaran}

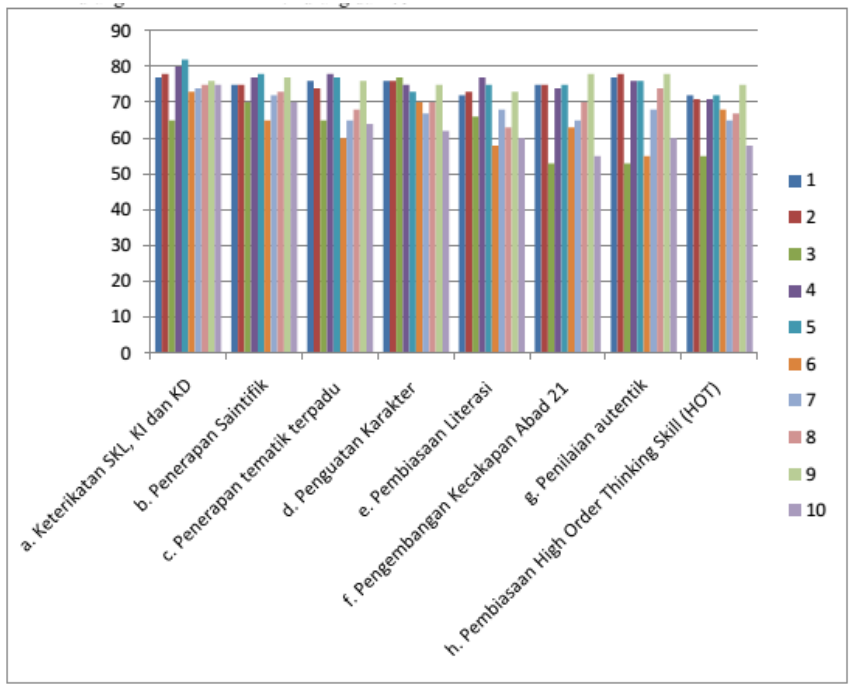

3. Temuan -temuan pada Siklus II

a. Peneliti selaku pengawas Dabin melaksanakan supervise akademik kolaburatif dengan teknik individual membimbing guru menyusun silabus, RPP, dan pelaksanaan pembelajaran dengan pembiasaan pengembangan abad 21 yaitu membimbing guru dalam pembelajaran agar siswa diberi kesempatan seluasluasnya untuk berpikir secara kreatif, kritis, kolaboratif, dan komunikatif. Hal ini dilakukan antara lain : guru dengan melaksanakan pembelajaran dengan membiasakan menerapkan saintifik setiap hari.

b. Guru berkomitmen melakukan pembelajaran dengan menerapkan Kurikulum 2013 dengan baik, dengan cara melaksanakan pembelajaran dengan menerapkan saintifik setiap hari.

c. Peneliti selaku supervisor berkomitmen meningkatkan supervise akademik kolaboratif teknik individual dengan baik.

d. Dengan meningkatnya kemampuan melaksanakan pembelajaran dengan menerapkan Kurikulum 2013 guru kelas I maka kualitas pembelajaran semakin meningkat. denagn demikian penerapan Kurikulum 2013 semakin baik.

e. grafik hasil penilaian siklus II

\section{Komponen Silabus}

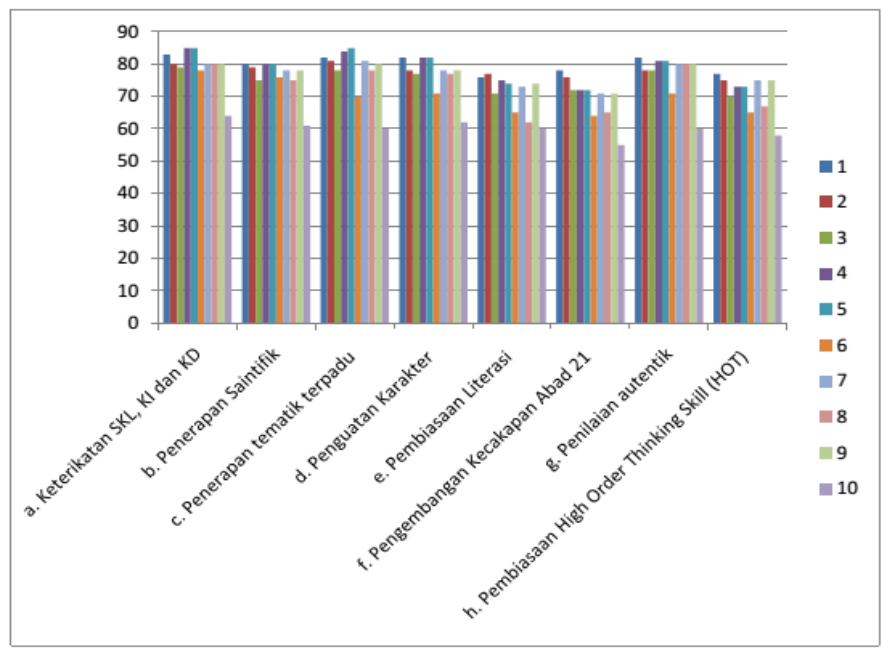




\section{Komponen RPP}

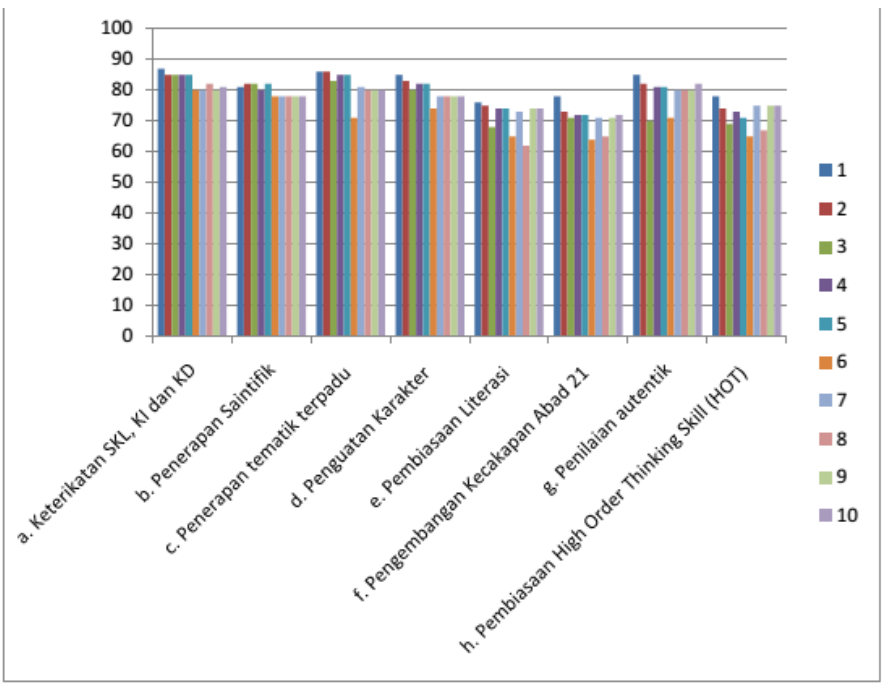

Komponen Pelaksanaan Pembelajaran

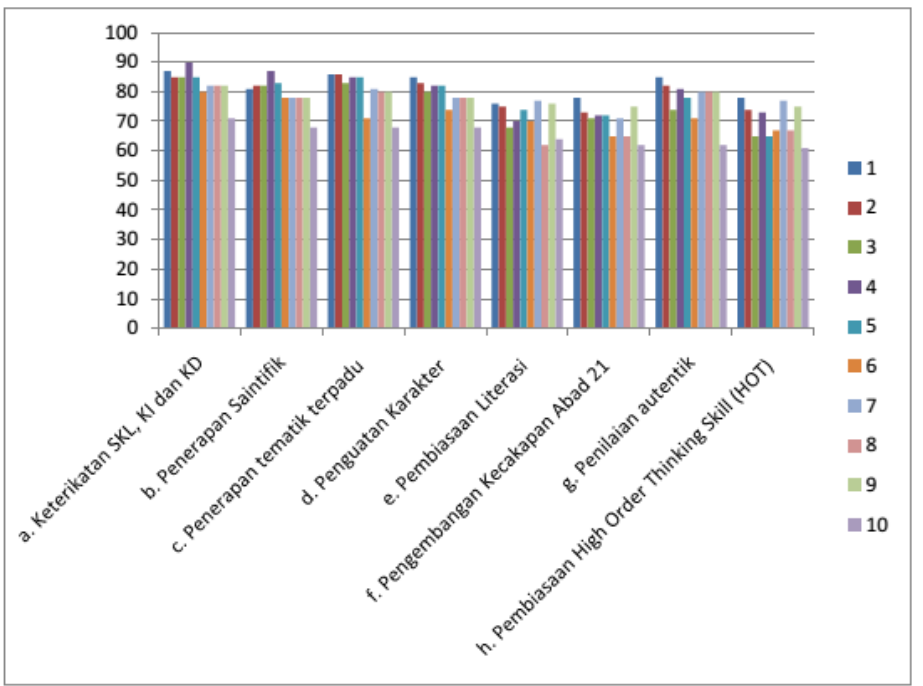

4. Temuan siklus III

a. Peneliti selaku pengawas Dabin melaksanakan supervise akademik kolaboratif dengan teknik individual membimbing guru menyusun silabus, RPP, dan pelaksanaan pembelajaran dengan lebih menekankan pembelajaran dengan menerapkan Kurikulum 2013 antara lain: nilai karakter dimplementasikan dalam pembelajaran( Penguatan Pendidikan Karakter), Menerapkan kegiatan -literasi dasar dalam pembelajaran, menerapkan langkah-langkah pembelajaran dengan saintifik, melakukan penilaian 3 aspek dengan menerapkan pembiasaan berpikir tingkat tinggi.

b. Guru telah menyususn silabus, RPP, dan pelaksanaan pembelajaran dengan menerapkan kurikulum 2013 dengan baik.

c. Dari hasil analisis penilaian diperoleh informasi bahwa guru kelas I telah melaksanakan pembelajaran dengan menerapkan Kurikulum 2013 dengan baik. Hal ini dihapkan berdampak pada prestasi belajar siswa maupun penguatan nilai karakter. 
d. Dengan meningkatnya kemampuan melaksanakan pembelajaran dengan menerapkan Kurikulum 2013 guru kelas I maka criteria keberhasilan kegiatan ini terca[pai dengan maksimal.

e. Grafik hasil penilaian siklus III

\section{Komponen Silabus}

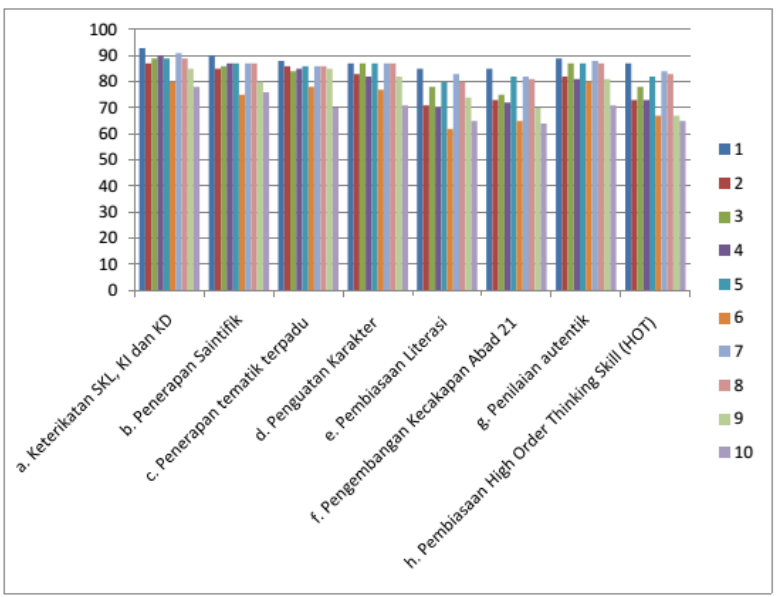

Komponen RPP

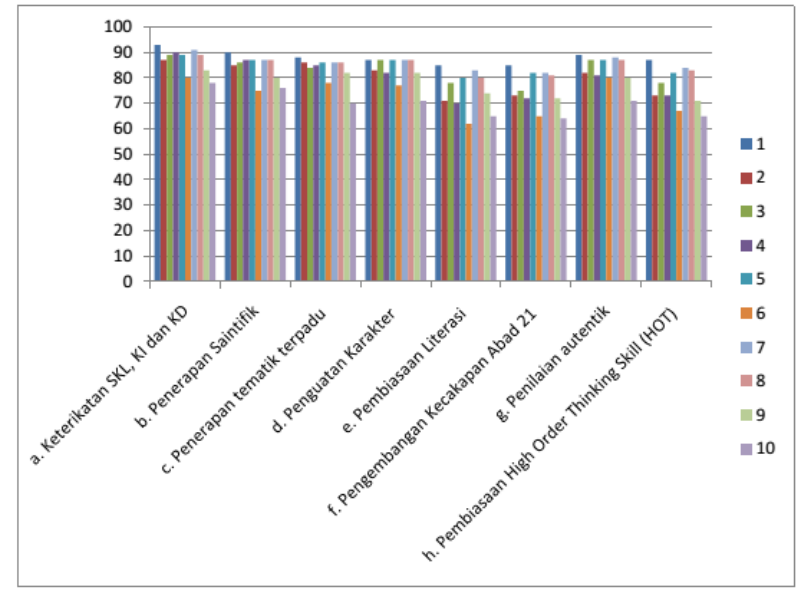

Komponen Pelaksanaan Pembelajaran

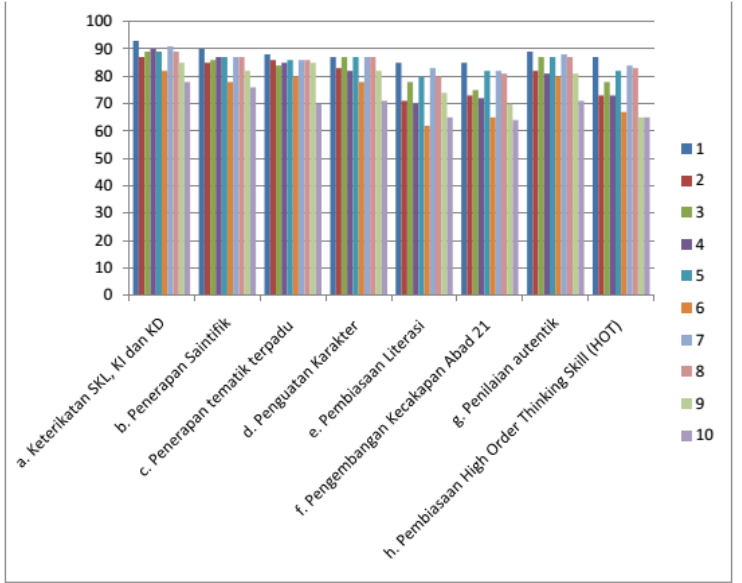




\section{SIMPULAN}

Berdasarkan hasil penelitian dan pembahasan masalah di atas, disimpulkan bahwa: Supervisi akademik kolaboratif teknik individual dapat meningkatkan kemampuan melaksanakan pembelajaran dengan menerapkan Kurikulum 2013 bagi guru kelas I di sekolah binaan Kecamatan Alian tahun 2018. Hal ini terbukti bahwa hasil rata-rata nilai setiap msiklus meningkat. Pada kondisi awal nilai rata-rata silabus guru kelas I adalah 62, 9. Nilai rata-rata RPP guru kelas I adalah 65, 7 . Nilai rata-rata pelaksanaan pembelajaran dengan menerapkan Kurikulum 2013 guru kelas I adalah 64,7 . Pada Siklus I nilai rata-rata silabus 72,6 . Nilai rata-rata $\operatorname{RPP} 72,2$, dan nilai ratarata pelaksanaan pembelajaran dengan menerapkan Kurikulum 2013 adalah 70,6. Pada siklus II nilai rata-rata silabus 74,8 . Nilai rata-rata RPP 77,0 . Nilai rata-rata pelaksanaan pembelajaran dengan menerapkan Kurikulum 2013 adalah 79,3. Siklus III nilai rata-rata silabus 79,8 . Nilai rata-rata RPP 81,5 . dan nilai rata-rata pelaksanaan pembelajaran dengan menerapkan Kurikulum 2013 adalah 83,9.Dengan demikian penelitian ini dinyatakan berhasil. Selaian itu, Nilai rata-rata guru menyusun silabus, RPP, dan pelaksanaan pembelajaran pada kondisi awal guru yang mendapat nilai kategori "baik" sebanyak 1 orang. Kemudian pada siklus I guru yang mendapat nilai kategori "baik" sebanyak 5 orang. Pada siklus III guru yang mendapat nilai kategori "baik" 7 orang, dan pada siklus III guru yang mendapat nilai dengan kategori "baik" sebanyak 8 orang. Dengan demikian penelitian ini dinyatakan berhasil.

Berdasarkan pada simpulan hasil penelitian tersebut, peneliti memberikan saran sebagai berikut :

1. Bagi Pengawas. Dalam rangka menyukseskan penerapan Kurikulum 2013 di SD hendaknya pengawas penting sekali untuk melaksanakan supervise akademik kolaboratif teknik individual untuk membantu para guru di dabinnya dalam melaksanakan tugas pembelajaran dengan menerapkan Kurikulum 2013.

2. Bagi Guru. Guru hendaknya harus mampu dan berupaya semaksimal mungkin dalam melaksanakan pembelajaran dengan menerapkan Kurikulum 2013 sesuai dengan ruh Kurikulum 2013sehingga mampu meningkatkan prestasi siswa dan penguatan nilai karakter menghadapi era di adab 21.

3. Bagi Kepala Sekolah. Kepala sekolah hendaknya selalu memberikan motivasi, bantuan, dorongan pada para guru agar dalam melaksanakan pembelajaran semangat menerapkan Kurikulum 2013. selain itu, kepala sekolah juga aktif melakukan supervisi akademik pada guru agar mengetahui secara langsung kemampuan guru dalam menerapkan Kurikulum 2013, serta membantu mengatasi kendala yang ada di sekolah dalam menerapkan Kurikulum 2013.

\section{DAFTAR PUSTAKA}

Abd.Kadim Masaong(2013).Supervisi Pembelajaran dan PengembanganKapasitas Guru: Memperdayakan pengawas sebagai Gurunya Guru.Bandung:Alfabeta.

Depdiknas(2008). Panduan Pembelajaran Tematik. Jakarta

Herabudin(2009).Administrasi dan Supervise Pendidikan.Bandung:CV Pustaka Setia.

Kemendikbud. (2017). Bimbingan Teknis Kurikulum 2013 jenjang SD. LPMP.Jateng.

Kemendikdub. (2014).Supervisi Akademik Implementasi Kurikulum 2013:Bahan Ajar untuk pengawas. Jakarta. 
Nana Sujana. (2002). Supervisi Pendidikan. Bandung: Rosdakarya.

Ngalim Purwanto (2008). Administrasi dan Supervisi Pendidikan.Bandung:Rosdakarya. Rachman,Edmund(2005). Berpikir Kritis dan Inovatif.Prestasi Pustakarya:Jakarta.

Soedijarto(1989). Menuju Pendidikan yang Relevan dan Bermutu.Gramedia :Jakarta.

Suharjono(1995). Kkarya Tulis Ilmiah di Bidang Pendidikan.Jakarta Departemen Pendidikan dan Kebudayaan.

Surakhmad, Winarno (2003) Memfasilitasi Pembelajaran yang Berkualitas, ditjen Dikdasmen depdiknas-JICA,Jakarta.

UURI No: 14 tahun 2015: tentang Guru dan Dosen,PB PGRI.Jakarta.

UURI No: 20 tahun 2003: Tentang Sistem pendidikan nasional (2006):Fokusmedia.Jakarta.

Zainal Aqib(2009). Penelitian Tindakan Sekolah. Yrama Widya. 